Research Article

\title{
Prevalence and Detection of qac Genes from Disinfectant-Resistant Staphylococcus aureus Isolated from Salon Tools in Ishaka Town, Bushenyi District of Uganda
}

\author{
Solange Gahongayire $\mathbb{C D}^{1}$ Adamu Almustapha Aliero $\left(\mathbb{D},{ }^{1}\right.$ Charles Drago Kato, ${ }^{1,2}$ \\ and Alice Namatovu ${ }^{1,3}$ \\ ${ }^{1}$ Department of Microbiology and Immunology, Faculty of Biomedical Sciences, Kampala International University, \\ Western Campus, P.O. Box 71, Bushenyi, Kampala, Uganda \\ ${ }^{2}$ School of Biosecurity, Biotechnical and Laboratory Sciences, College of Veterinary Medicine, Animal Resources and Biosecurity, \\ Makerere University, P.O. Box 7062, Kampala, Uganda \\ ${ }^{3}$ Department of Biotechnical and Diagnostic Sciences, College of Veterinary Medicine, Animal Resources and Biosecurity, \\ Makerere University, P. O. Box 7062, Kampala, Uganda
}

Correspondence should be addressed to Solange Gahongayire; solangeg@stud.kiu.ac.ug

Received 5 February 2020; Revised 6 June 2020; Accepted 29 July 2020; Published 12 August 2020

Academic Editor: Pietro Mastroeni

Copyright (c) 2020 Solange Gahongayire et al. This is an open access article distributed under the Creative Commons Attribution License, which permits unrestricted use, distribution, and reproduction in any medium, provided the original work is properly cited.

\begin{abstract}
Bacterial infections are on a rise with causal-resistant strains increasing the economic burden to both patients and healthcare providers. Salons are recently reported as one of the sources for transmission of such resistant bacterial strains. The current study aimed at the identification of the prevalent bacteria and characterization of quaternary ammonium compound ( $q a c)$ genes from disinfectant-resistant S. aureus isolated from salon tools in Ishaka town, Bushenyi District of Uganda. A total of 125 swabs were collected from different salon tools (combs, brushes, scissors, clippers, and shaving machines), and prevalent bacteria were isolated using standard microbiological methods. Identification of isolated bacteria was done using standard phenotypic methods including analytical profile index (API). Susceptibility patterns of the isolated bacteria to disinfectant were determined using the agar well diffusion method. Quaternary ammonium compound ( $q a c)$ genes ( $q a c \mathrm{~A} / \mathrm{B}$ and $q a c \mathrm{C}$ ) associated with disinfectant resistances were detected from disinfectant-resistant $S$. aureus using multiplex polymerase chain reaction (PCR) and Sanger sequencing methods. Of the 125 swab samples collected from salons, 78 (62.4\%) were contaminated with different bacteria species. Among the salon tools, clippers had the highest contamination of $20(80.0 \%)$, while shaving machines had the lowest contamination of 11 (44.0\%). The most prevalent bacteria identified were Staphylococcus epidermidis (28.1\%) followed by S. aureus (26.5\%). Of all the disinfectants tested, the highest resistance was shown with sodium hypochlorite $1 \%$. Out of the eight (8) disinfectant-resistant S. aureus analysed for qac genes, 2 (25\%) isolates (STP6 and STP9) were found to be qacA/B positive, while 2 (25\%) isolates (STP8 and STP9) were found to be qacC gene positive. This study has shown that bacterial contamination of salon tools is common, coupled with resistance to disinfectants with sodium hypochlorite resistance being more common. Furthermore, observed resistance was attributed to the presence of qac genes among $S$. aureus isolates. A search for qac genes for disinfectant resistance from other bacteria species is recommended.
\end{abstract}

\section{Introduction}

Worldwide, skin infections are among the important causes of morbidity [1-3]. Among these infections are those caused by different bacteria which are common in most developing countries [4]. These infections can be spread through different ways including direct contact with bodily fluids from contaminated blood, pus, sores, cuts, or grazes $[5,6]$. Beauty salons (defined as places where hair, face, and body can be given special treatments to improve their appearance) pose 
potential health risks to clients and service providers in terms of skin infections and sometimes physical injuries $[7,8]$. Therefore, bacterial skin infections can be acquired from different inanimate objects depending on the nature of the service sought, tools and equipment used, the health status of the clients and service providers, as well as the infection control procedures implemented [5].

Several bacteria, viruses, and fungi especially yeasts have been isolated from manicure, pedicure, hairdressing, and barbering equipment [8-12]. Studies done in the United States of America on manicure and pedicure showed evidence of Streptococcus spp., Enterococcus spp., Micrococcus spp., Bacillus spp., Enterobacter spp., Klebsiella spp., Acinetobacter spp., Citrobacter spp., and Escherichia coli $[11,13]$. Other studies from California [12], two urban and two semiurban areas in South Africa [14], Cincinnati [15], and North Carolina counties, USA [16], on some tools also isolated other bacteria such as Mycobacterium fortuitum, $M$. chelonae, and M. mageritense. Similarly, studies from Abia state, Nigeria [8], Adamawa state, Nigeria [17], and Pakistan [10] based on in-use tools in hairdressing and barbering showed contamination by bacteria like $S$. aureus, Pseudomonas aeruginosa, S. epidermidis, Streptococcus spp., Enterococcus spp., and Enterobacter spp. However, fewer studies have investigated the role of salons in the spread of drug-resistant pathogens, especially in Africa.

Proper use of disinfectants can help contain and prevent the spread of these pathogens from inanimate objects. However, the study has revealed resistance of some microorganisms on a different type of disinfectants [18]. A study done by Guimarães et al. [19] on different disinfectants revealed that bacteria resistance to phenols and quaternary ammonium compound (qac) was common. Among these resistant strains were methicillin-resistant $S$. aureus (MRSA), S. epidermidis, Enterobacter cloacae, Proteus mirabilis, Serratia marcescens, and P. aeruginosa. Several factors such as concentration used, application method, the contact time of the disinfectant, and the safety considerations for operators to apply disinfectants may affect the effectiveness of disinfectants [20-22]. Uganda National Bureau of Standard (UNBS) [23] gives guidelines pertaining to the usage of disinfectants; however, it is not clear if they are followed by salons in Uganda. Furthermore, UNBS recommends testing for effectiveness of disinfectants, but there is a paucity of such studies in Uganda, and the role of the salon in the spread of infections in Uganda has not yet been elucidated. This study, therefore, explored the effectiveness of the commonly used disinfectants and identified the genes associated with disinfectant resistance in some of the resistant strains obtained from salon tools in Bushenyi district, Uganda.

\section{Materials and Methods}

2.1. Study Design. The cross-sectional study was carried out on selected beauty salons in Ishaka town located in Bushenyi district of Uganda. Different salons barbershops, hairdressing/ladies salons, and unisex salons were selected purposively based on salons who claim to use disinfectants and others methods to sterilize their materials, while the choice of selected tools was in accordance with literature indicating that the tools selected for this study are the most commonly contaminated [9].

2.2. Sample Collection. One hundred and twenty-five (125) swab samples collected from different salons barbershops, hairdressing/ladies salons, and unisex salons. Twenty-five (25) samples each were collected from different salon tools such as combs, brushes, scissors, clippers, and shaving machines using moistened swabs with $0.85 \%$ normal saline according to the method described by Enemuor et al. [9]. Swabs were later inserted in sterile $5 \mathrm{ml}$ tubes containing $2 \mathrm{ml}$ of Stuart transport medium and transported in ice box cooler to the Microbiology Laboratory, Kampala International University Western Campus for further analysis.

2.3. Isolation and Identification of Bacteria. Isolation and identification of bacteria were done using standard microbiological protocols. Primary isolation of bacteria was done by inoculating the swabs on nutrient agar plates and then incubated at $37^{\circ} \mathrm{C}$ for $18-24$ hours. The suspected bacteria were subcultured on blood agar plates and incubated at $37^{\circ} \mathrm{C}$ for 18-24 hours. Later colonies examined for hemolytic characteristics (alpha, beta, or gamma). Furthermore, bacterial isolates were confirmed to species level using colony morphology from different media (including nutrient agar, blood agar, Mannitol salt agar, and MacConkey agar), Grams staining, and biochemical tests. Deferoxamine susceptibility test was done to differentiate between $S$. aureus and other Staphylococcus spp. where S. hominis and S. epidermidis are sensitive, while $S$. aureus is resistant. Fosfomycin susceptibility test was also carried out to confirm $S$. epidermidis isolate [24]. Staphylococcus spp. were further confirmed using analytical profile index (API) system [25].

2.4. Disinfectants Susceptibility Test. Disinfectants susceptibility tests were done using the agar well diffusion method as described by Günther et al. [26] with some modifications. The bacterial inocula were standardized with $0.5 \mathrm{McF}$ arland standard solutions. This was inoculated on freshly prepared Mueller-Hinton agar (MHA) using sterile swabs after which wells were made using sterile cork borer $(6 \mathrm{~mm})$. The concentration of different disinfectant was prepared: methylated spirit (70\%), sodium hypochlorite (1\%), and surgical spirit BP (70\%). Amoxicillin $0.1 \mathrm{mg} / \mathrm{ml}$ and sterile distilled water were used as positive and negative controls, respectively. A hundred microliters $(100 \mu \mathrm{l})$ of each disinfectant, positive and negative controls, were pipetted using a sterile pipette (100-1000 $\mu \mathrm{l}$ Eppendorf ${ }^{\mathrm{TM}}$, Reference ${ }^{\mathrm{TM}}$, Fisher Scientific) and filled into the well and allowed to stand for 10 minutes after which the plates were incubated at $37^{\circ} \mathrm{C}$ for 18-24 hr [27]. Inhibition zones were observed after the incubation period and were interpreted based on the absence or presence of inhibition zone and interpreted according to International Clinical Laboratory Standard guidelines [28]. 


\subsection{Molecular Detection of qac Genes}

2.5.1. DNA Extraction. Genomic DNA extraction was done on the eight $S$. aureus isolates that showed resistance to all disinfectants. Extraction of DNA was done according to the method previously described [29] with some slight modifications. In brief, $500 \mu \mathrm{l}$ of the $24 \mathrm{hr}$ culture was mixed with $500 \mu \mathrm{l}$ of reagent grade water and heated at $100^{\circ} \mathrm{C}$ for 10 minutes and later centrifuged at $15000 \mathrm{rpm}$ for $15 \mathrm{~min}$. The supernatant containing genomic DNA was then conserved in $-20^{\circ} \mathrm{C}$ until use for polymerase chain reaction (PCR) amplification experiments.

2.5.2. PCR Amplification and Sequencing. The primers sequences used were as follows: qacA/B: forward primer $5^{\prime}$ CTAT GGCAATAGG AGA TATGGTGT, reverse primer 5'-CCACTACAGATTCTTCAGCTACATG-3'; qacC: forward primer5'-AAACAATGCAACACCTACCACT, reverse primer 5'-AACG AAACTA CGCC GACTATG-3' [30]. PCR was performed in $25 \mu \mathrm{l}$ final reaction volume containing $6 \mu \mathrm{l}(50 \mathrm{ng})$ of bacterial extracted DNA from $S$. aureus-resistant species and then added $2 \mu \mathrm{l}$ of forward primer $(10 \mathrm{pmol}), 2 \mu \mathrm{l}$ of reverse primer $(10 \mathrm{pmol})$, Taq $12.5 \mu \mathrm{l}$ master mix solution, and $2.5 \mu \mathrm{l}$ of nuclease-free water. Amplification was done in Thermal Cycler (Model 480, Perkin-Elmer Cetus, Foster City, CA, USA). The PCR was performed under the following conditions: initial denaturation at $95^{\circ} \mathrm{C}$ for $3 \mathrm{~min}$, then 35 cycles of three-step PCR amplification consisting of denaturation at $94^{\circ} \mathrm{C}$ for $1 \mathrm{~min}$, primer annealing at $55^{\circ} \mathrm{C}$ for 30 seconds, and extension at $72^{\circ} \mathrm{C}$ for $2 \mathrm{~min}$, and final extension was attained for $10 \mathrm{~min}$ [29, 30]. Following PCR amplification, the product was digested with $5 \mathrm{U}$ of restriction enzyme (Alu-I) at $37^{\circ} \mathrm{C}$ for $90 \mathrm{~min}$ and after the product was analysed using electrophoresis on a $2 \%(\mathrm{w} / \mathrm{v})$ agar rose $/ 1 \times \mathrm{TBE}$ buffer. The expected sizes of amplified fragments of qacB, qacA, and qacC genes were $176 \mathrm{bp}, 220 \mathrm{bp}$, and 149, respectively [30]. The amplified products were photographed, and their size was determined using a 25 bp molecular size marker (Promega, USA). After gel electrophoresis, the positive isolates were further confirmed by sequencing using the Sanger sequencing method as described by Xiao et al. [31]. All PCR and sequencing work were done at Inqaba biotechnology laboratory company, South Africa.

2.6. Data Analysis. Data were entered in MS excel after being edited and cleaned of any obvious errors. The data were then analysed using the Statistical Package for Social Sciences (SPSS), version 21 software. Data on prevalent bacteria on the contaminated beauty salon tools were presented in the form of percentages, comparison among salon tools was done using a chi-square test, and $p$ value $\leq 0.05$ was considered significant. Disinfectant-resistant genes ( $q a c$ ) identified from Staphylococcus species were analysed using BLAST search (https://blast.ncbi.nlm.nih.gov/Blast.cgi) in order to obtain the phylogenetic tree. The obtained sequences (of related Staphylococcus species with qac genes from NCBI) and our sequences were aligned using the
MUSCLE alignment method, and a phylogenetic tree was constructed using join maximum likelihood using 1000 bootstrap replica. All sequences were analysed using MEGA software version 6.0. The constructed phylogenetic tree was interpreted accordingly especially the formation clade of our isolates and other known isolates obtained from NCBI. A clade consists of an organism and all of its descendants.

2.7. Ethical Considerations. Ethical clearance was sought from the Research Ethics Committee of Kampala International University Western Campus (KIU-WC) (Ref: SF201813). Salon owners' approval was obtained to collect samples from different tools.

\section{Results}

3.1. Prevalent Bacteria Isolated from Beauty Salon Tools. Out of 125 salons tools swabbed, 78 (62.4\%) were contaminated with a total of 196 different bacterial isolates identified. On comparison of microbial load across the different saloon tools, clippers were found to have a higher contamination among the salon tools studied $(80.0 \%)$, followed by brushes (76.0\%), scissors (64.0\%), combs (48.0\%), and shaving machine (44.0\%) (Table 1). The most prevalent bacteria identified were S. epidermidis $(28.1 \%)$ and S. aureus (26.5\%). Other bacterial species involved in the contamination of salon tools were Streptococcus spp. (16.8\%), Micrococcus spp. (12.8\%), S. xylosus (8.8\%), P. aeruginosa (8.0\%), Enterobacter aerogenes (6.4\%), Serratia liquefaciens (6.4\%), Bacillus subtilis (4.8\%), Bacillus spp. (4.0\%), Serratia marcescens (1.6\%), Enterobacter spp. $(0.8 \%)$, and Staphylococcus sciuri $(0.8 \%)$, as indicated in Table 2.

The distribution of bacterial contaminant according to the type of salons showed that barbershops and unisex salons had the highest distribution with (37\%) each, while hairdressing/ladies salons had the least (27.0\%) (Table 3).

3.2. Susceptibility Patterns of Isolated Bacteria to Commonly Used Disinfectants. Out of the 137 bacterial isolates subjected to disinfectant susceptibility tests, 37 (27.0\%) were resistant to $1 \%$ sodium hypochlorite and $22(16.0 \%)$ to $70 \%$ surgical spirit BP, while $4(2.9 \%)$ were resistant to methylated spirit (70\%). It was observed that some isolates of $S$. epidermidis, S. xylosus, and E. aerogenes were resistant to both surgical spirit BP (70\%) and sodium hypochlorite (1\%). However, $S$. marcescens isolates were found to be resistant to both methylated spirit (70\%) and sodium hypochlorite (1\%), while isolates of $S$. aureus were found to be resistant to all three disinfectants, i.e., surgical spirit BP (70\%), sodium hypochlorite (1\%), and methylated spirit (70\%).

The resistant pattern of bacterial isolates to disinfectants varies. S. liquefaciens isolates showed $87 \%$ resistant to surgical spirit BP (70\%), S. marcescens showed 50\% resistant to methylated spirit (70\%), while S. liquefaciens, S. marcescens, and S. sciuri showed $100 \%$ resistant to sodium hypochlorite (1\%). The distribution of resistance according to the bacterial species showed that $S$. liquefaciens, S. marcescens, and $S$. sciuri were $100 \%$ resistant to sodium hypochlorite, while $S$. epidermidis showed low resistance (3.6\%). Similarly, $S$. 
TABLE 1: Contamination of beauty salon tools in Ishaka town, Uganda.

\begin{tabular}{|c|c|c|c|c|}
\hline \multirow{2}{*}{ Salon tools } & \multirow{2}{*}{ Number examined } & \multicolumn{2}{|c|}{ Contamination } & \multirow{2}{*}{$p$ value } \\
\hline & & Positive, $n(\%)$ & Negative, $n(\%)$ & \\
\hline Clippers & 25 & $20(80.0)$ & $5(20.0)$ & $0.034^{*}$ \\
\hline Brushes & 25 & $19(76.0)$ & $6(24.0)$ & $0.04^{*}$ \\
\hline Scissors & 25 & $16(64.0)$ & $9(36.0)$ & 0.52 \\
\hline Combs & 25 & $12(48.0)$ & $13(52.0)$ & 0.32 \\
\hline Shaving machine & 25 & $11(44.0)$ & $14(56.0)$ & 0.43 \\
\hline Total & 125 & $78(62.4)$ & $47(37.6)$ & \\
\hline
\end{tabular}

*Statistically significant at $p \leq 0.05$.

TABle 2: Prevalent bacteria isolated from beauty salon tools in Ishaka town, Uganda.

\begin{tabular}{|c|c|c|c|c|c|}
\hline Organisms & Barbershops $n(\%)$ & Hairdressing/ladies salons $n(\%)$ & Unisex salons $n(\%)$ & Total (\%) & $p$ value \\
\hline S. epidermidis & $21(10.7)$ & $18(9.2)$ & $16(8.2)$ & $55(28.1)$ & $0.045^{*}$ \\
\hline S. aureus & $12(6.1)$ & $12(6.1)$ & $28(14.3)$ & $52(26.5)$ & $0.02^{*}$ \\
\hline Streptococcus spp. & $8(4.1)$ & $7(3.6)$ & $7(3.6)$ & $22(11.2)$ & 0.061 \\
\hline Micrococcus spp. & $5(2.6)$ & $5(2.6)$ & $6(3.1)$ & $16(8.2)$ & 0.06 \\
\hline S. xylosus & $5(2.6)$ & $2(1.0)$ & $4(2.0)$ & $11(5.6)$ & 0.53 \\
\hline P. aeruginosa & $4(2.0)$ & $3(1.5)$ & $3(1.5)$ & $10(5.1)$ & 0.54 \\
\hline S. liquefaciens & $3(1.5)$ & $3(1.5)$ & $2(1.0)$ & $8(4.1)$ & $0.04^{*}$ \\
\hline E. aerogenes & $5(2.6)$ & $0(0.0)$ & $3(1.5)$ & $8(4.1)$ & 0.71 \\
\hline B. subtilis & $3(1.5)$ & $2(1.0)$ & $1(0.5)$ & $6(3.1)$ & 0.32 \\
\hline Bacillus spp. & $4(2.0)$ & $0(0.0)$ & $1(0.5)$ & $5(2.6)$ & 0.52 \\
\hline S. marcescens & $2(1.0)$ & $0(0.0)$ & $0(0.0)$ & $2(1.0)$ & 0.63 \\
\hline S. sciuri & $0(0.0)$ & $0(0.0)$ & $1(0.5)$ & $1(0.5)$ & 1.0 \\
\hline Total & $72(37.0)$ & $52(27.0)$ & $56(37.0)$ & $196(100.0)$ & \\
\hline
\end{tabular}

* Statistically significant at $p \leq 0.05$.

TABLe 3: Prevalent bacteria isolated from beauty salon in Ishaka town, Uganda, according salon tool.

\begin{tabular}{|c|c|c|c|c|c|c|c|}
\hline Organisms & Comb (\%) & Brush (\%) & Clipper (\%) & Scissor (\%) & Shaving machine (\%) & Total (\%) & $p$ value \\
\hline S. epidermidis & $8(14.5)$ & $14(25.5)$ & $18(32.7)$ & $9(16.4)$ & $6(10.9)$ & $55(28.1)$ & 0.70 \\
\hline S. aureus & $9(17.6)$ & $12(23.5)$ & $14(27.5)$ & $7(11.8)$ & $10(19.6)$ & $52(26.5)$ & 0.67 \\
\hline Streptococcus spp. & $0(0.0)$ & $7(33.3)$ & $6(28.6)$ & $6(28.6)$ & $3(14.3)$ & $22(11.2)$ & $0.057^{*}$ \\
\hline Micrococcus spp. & $2(12.5)$ & $2(12.5)$ & $4(25.0)$ & $4(25.0)$ & $4(25.0)$ & $16(8.2)$ & 0.56 \\
\hline S. xylosus & $4(36.4)$ & $2(18.2)$ & $0(0.0)$ & $2(18.2)$ & $3(27.3)$ & $11(5.6)$ & $0.04^{*}$ \\
\hline P. aeruginosa & $3(30.0)$ & $2(20.0)$ & $2(20.0)$ & $1(10.0)$ & $2(20.0)$ & $10(5.1)$ & 0.46 \\
\hline S. liquefaciens & $5(62.5)$ & $0(0.0)$ & $1(12.5)$ & $1(12.5)$ & $1(12.5)$ & $8(4.1)$ & $0.002^{*}$ \\
\hline E. aerogenes & $0(0.0)$ & $2(25.0)$ & $1(12.5)$ & $3(37.5)$ & $2(25.0)$ & $8(4.0)$ & 0.34 \\
\hline B. subtilis & $0(0.0)$ & $3(50.0)$ & $1(16.7)$ & $2(33.3)$ & $0(0.0)$ & $6(3.1)$ & $0.03^{*}$ \\
\hline Bacillus spp. & $1(20.0)$ & $1(20.0)$ & $2(40.0)$ & $1(20.0)$ & $0(0.0)$ & $5(2.6)$ & 0.068 \\
\hline S. marcescens & $0(0.0)$ & $0(0.0)$ & $2(100.0)$ & $0(0.0)$ & $0(0.0)$ & $2(1.0)$ & - \\
\hline S. sciuri & $0(0.0)$ & $0(0.0)$ & $0(0.0)$ & $1(100.0)$ & $0(0.0)$ & $1(0.5)$ & - \\
\hline
\end{tabular}

${ }^{*}$ Statistically significant at $p$ value $\leq 0.05$.

liquefaciens showed high resistance (87.5\%) to 70\% surgical spirit BP among the bacteria tested, while $S$. marcescens and S. sciuri showed no resistance $(0.0 \%)$ to this disinfectant. $S$. marcescens was found to be the most resistant bacterial to methylated spirit, while S. epidermidis, S. xylosus, E. aerogenes, and S. sciuri showed no resistance (0.0\%) (Table 4$)$.

The results on the distribution of resistant bacterial isolates according to salon type showed that barbershops had the highest distribution of resistant bacterial isolates 20 (41.7\%), while hairdressing/ladies salons had the lowest resistant bacterial isolates $5(14.3 \%)$. From the barbershop salons, it was observed that $S$. liquefaciens, E. aerogenes, and S. liquefaciens showed $100 \%$ resistance to the disinfectant, while $S$. sciuri had no resistance to the disinfectants tested.
However, it was also observed that S. liquefaciens from hairdressing/ladies salons showed $100 \%$ resistance to the disinfectants tested, while S. epidermidis, S. xylosus, E. aerogenes, $S$. marcescens, and $S$. sciuri showed no resistance to the disinfectant tested. In unisex salons, S. liquefaciens, E. aerogenes, and S. sciuri showed $100 \%$ resistance to disinfectants tested, while $S$. marcescens showed no resistance (Table 5).

3.3. Characterization of qac Genes from S. aureus. Eight isolates of $S$. aureus that showed resistance to all the three disinfectants were subjected to Multiplex PCR for detection of $q a c \mathrm{~A} / \mathrm{B}$ and $q a c \mathrm{C}$ genes associated with disinfectant 
TABLE 4: Disinfectant-resistant bacterial isolates in Ishaka town, Uganda.

\begin{tabular}{|c|c|c|c|c|}
\hline \multirow[b]{2}{*}{ Organisms } & \multirow[b]{2}{*}{ No. examined } & \multicolumn{3}{|c|}{ Types of disinfectants tested } \\
\hline & & $\begin{array}{l}\text { Surgical spirit BP }(70 \%) \\
\text { Resistant strains (\%) }\end{array}$ & $\begin{array}{c}\text { Methylated spirit }(70 \%) \\
\text { Resistant strains (\%) }\end{array}$ & $\begin{array}{c}\text { Sodium hypochlorite (1\%) } \\
\text { Resistant strains (\%) }\end{array}$ \\
\hline S. epidermidis & 55 & $2(3.6)$ & $0(0.0)$ & $2(3.6)$ \\
\hline S. aureus & 52 & $8(15.3)$ & $2(3.8)$ & $9(17.3)$ \\
\hline S. xylosus & 11 & $3(27.2)$ & $0(0.0)$ & $8(72.7)$ \\
\hline S. liquefaciens & 8 & $7(87.5)$ & $1(12.5)$ & $8(100.0)$ \\
\hline E. aerogenes & 8 & $2(25.0)$ & $0(0.0)$ & $7(87.5)$ \\
\hline S. marcescens & 2 & $0(0.0)$ & $1(50.0)$ & $2(100.0)$ \\
\hline S. sciuri & 1 & $0(0.0)$ & $0(0.0)$ & $1(100.0)$ \\
\hline Total & 137 & $22(16.1)$ & $4(2.9)$ & $37(27.0)$ \\
\hline
\end{tabular}

TABLE 5: Distribution of resistant bacteria isolates based on type of salons from Ishaka town, Uganda.

\begin{tabular}{|c|c|c|c|c|c|c|}
\hline \multirow{3}{*}{ Organisms } & \multicolumn{6}{|c|}{ Types of salons } \\
\hline & \multicolumn{2}{|c|}{ Barbershops } & \multicolumn{2}{|c|}{ Hairdressing/ladies salons } & \multicolumn{2}{|c|}{ Unisex salons } \\
\hline & No. examined & Resistant, $n(\%)$ & No. examined & Resistant, $n(\%)$ & No. examined & Resistant, $n(\%)$ \\
\hline S. aureus & 12 & $5(41.6)$ & 12 & $2(16.6)$ & 28 & $2(7.1)$ \\
\hline S. epidermidis & 21 & $1(4.7)$ & 18 & $0(0)$ & 16 & $1(6.25)$ \\
\hline S. liquefaciens & 3 & $3(100)$ & 3 & $3(100)$ & 2 & $2(100)$ \\
\hline S. xylosus & 5 & $5(100)$ & 2 & $0(0)$ & 4 & $3(75)$ \\
\hline E. aerogenes & 5 & $4(80)$ & 0 & $0(0)$ & 3 & $3(100)$ \\
\hline S. marcescens & 2 & $2(100)$ & 0 & $0(0)$ & 0 & $0(0)$ \\
\hline S. sciuri & 0 & $0(0)$ & 0 & $0(0)$ & 1 & $1(100)$ \\
\hline Total & 48 & $20(41.7)$ & 35 & $5(14.3)$ & 54 & $12(32)$ \\
\hline
\end{tabular}

$n$, number; \%, percentage.

resistance. Approximately, 220 base pair (bp) and 249 base pair (bp) amplicon size were obtained for qacA and qacC genes, respectively. Out of the eight (8) bacterial isolates that were analysed for qac genes, 2 (25\%) isolates (STP6 and STP9) were found to be qacA gene positive, while 2 (25\%) isolates (STP8 and STP9) were found to be qacC gene positive.

Sequence analysis results for both isolates showed that the antiseptic resistance protein (qacA) gene sequence of the two S. aureus was $100 \%$ similar to about 17 Staphylococcus spp. (Table 6). A phylogenetic tree was constructed using the maximum likelihood statistical method at 1000 number of bootstrap replication results from the phylogenetic tree did not yield any significant bootstrap values (Figure 1).

\section{Discussion}

Bacterial infections from resistant strains are on the rise causing an increased economic burden to both patients and healthcare providers $[2,3]$. Salon shops have been incriminated in the spread of these bacterial pathogens including resistant strains $[37,38]$. The resistance of these bacteria to disinfectant can lead to failure to fight both community- and hospital-acquired infections [39]. Detection of genes associated with disinfectant resistance is clinically important in the treatment of these infections as these genes vary and confer reduced susceptibility to commonly used antiseptics and disinfectants [40]. This study was therefore designed to determine prevalence and susceptibility of bacteria isolated from salons to commonly used disinfectants in Ishaka town, Bushenyi District of Uganda. The prevalence of bacterial contamination from studied salons in this study was lower compared to the findings of Enemuor et al. [9] who reported $100 \%(n=42)$ prevalence of hairdressing and beauty salons tools contamination from Nigeria and so was the finding from a study by Dadashi and Dehghanzadeh [40] on shared cosmetic kits in women beauty salons in Iran. The lower prevalence found in this study could be due to the awareness of the majority ( $88 \%$ ) of the salon's operators on biosafety guideline. According to Guimarães et al. [19], the higher prevalence of contamination found in their study could be due to inappropriate sterilization techniques used by these salon operators in which $38 \%$ of their studied participants used ultraviolet (UV) light, $18 \%$ used glass beads, and 1\% used ultrasonic cleaners, all of which are not approved methods of sterilization in many jurisdictions [41].

The isolation of $S$. epidermidis as the most frequently isolated bacteria contaminant from salons tools was contrary to the findings of Enemuor et al. [9] and Dadashi and Dehghanzadeh [40] who reported higher distribution of $S$. aureus from hairdressing and beauty salons tools. Isolation of bacteria from studied salons tools in the current study probably indicates that the disinfectant or sterilization methods used by salon operators were not effective or failure to use disinfectants. The contamination of all salons tools with clippers having the highest contamination was in line with the study by Omoruyi and Idemudia [21], who reported prevalence of $91.67 \%, 75 \%$, and $83.3 \%$ of Staphylococcus, 
TABle 6: Blast comparison between S. aureus disinfectant resistance protein (qacA) genes identified and other Staphylococcus spp. in Gene Bank using NCBI Blast.

\begin{tabular}{|c|c|c|c|c|c|c|}
\hline No. & Organisms & Sequence & Accession number & References & Percentage identity (\%) & $E$ value \\
\hline 1 & S. aureus & STP6 & NA & This study & 100.00 & 0.027 \\
\hline 2 & S. aureus & STP9 & NA & This study & 100.00 & 0.027 \\
\hline 3 & S. aureus & NSNJ5 & LC335721.1 & Saber et al. [32] & 100.00 & 0.027 \\
\hline 4 & S. aureus & NSNJ4 & LC335720.1 & Saber et al. [32] & 100.00 & 0.027 \\
\hline 5 & S. aureus & NSNJ3 & LC335719.1 & Saber et al. [32] & 100.00 & 0.027 \\
\hline 6 & S. aureus & NSNJ2 & LC335718.1 & Saber et al. [32] & 100.00 & 0.027 \\
\hline 7 & S. aureus & NSNJ1 & LC335717.1 & Saber et al. [32] & 100.00 & 0.027 \\
\hline 8 & S. aureus & TPS89 pTZ2089 & NG_048037.1 & Nakaminami et al. [33] & 100.00 & 0.027 \\
\hline 9 & S. aureus & Teh11 & KР687798.1 & Hassanzadeh et al. [34] & 100.00 & 0.027 \\
\hline 10 & S. aureus & FJ857944.1 & FJ857944.1 & Zhou et al. [35] & 100.00 & 0.027 \\
\hline 11 & S. epidermidis & MK040371.1 strain 20.1 & MK040371.1 & Addetia et al. [36] & 100.00 & 0.027 \\
\hline 12 & S. epidermidis & MK040366.1 strain 106.1 & MK040366.1 & Addetia et al. [36] & 100.00 & 0.027 \\
\hline 13 & S. epidermidis & MK040365.1 strain 99.1 & MK040365.1 & Addetia et al. [36] & 100.00 & 0.027 \\
\hline 14 & S. epidermidis & MK040364.1 strain 68.5 & MK040364.1 & Addetia et al. [36] & 100.00 & 0.027 \\
\hline 15 & S. epidermidis & MK040363.1 strain 66.3 & MK040363.1 & Addetia et al. [36] & 100.00 & 0.027 \\
\hline 16 & S. hominis & MK040362.1 strain 125.1 & MK040362.1 & Addetia et al. [36] & 100.00 & 0.027 \\
\hline 17 & S. epidermidis & MK040362.1 strain 36.5 & MK040361.1 & Addetia et al. [36] & 100.00 & 0.027 \\
\hline
\end{tabular}

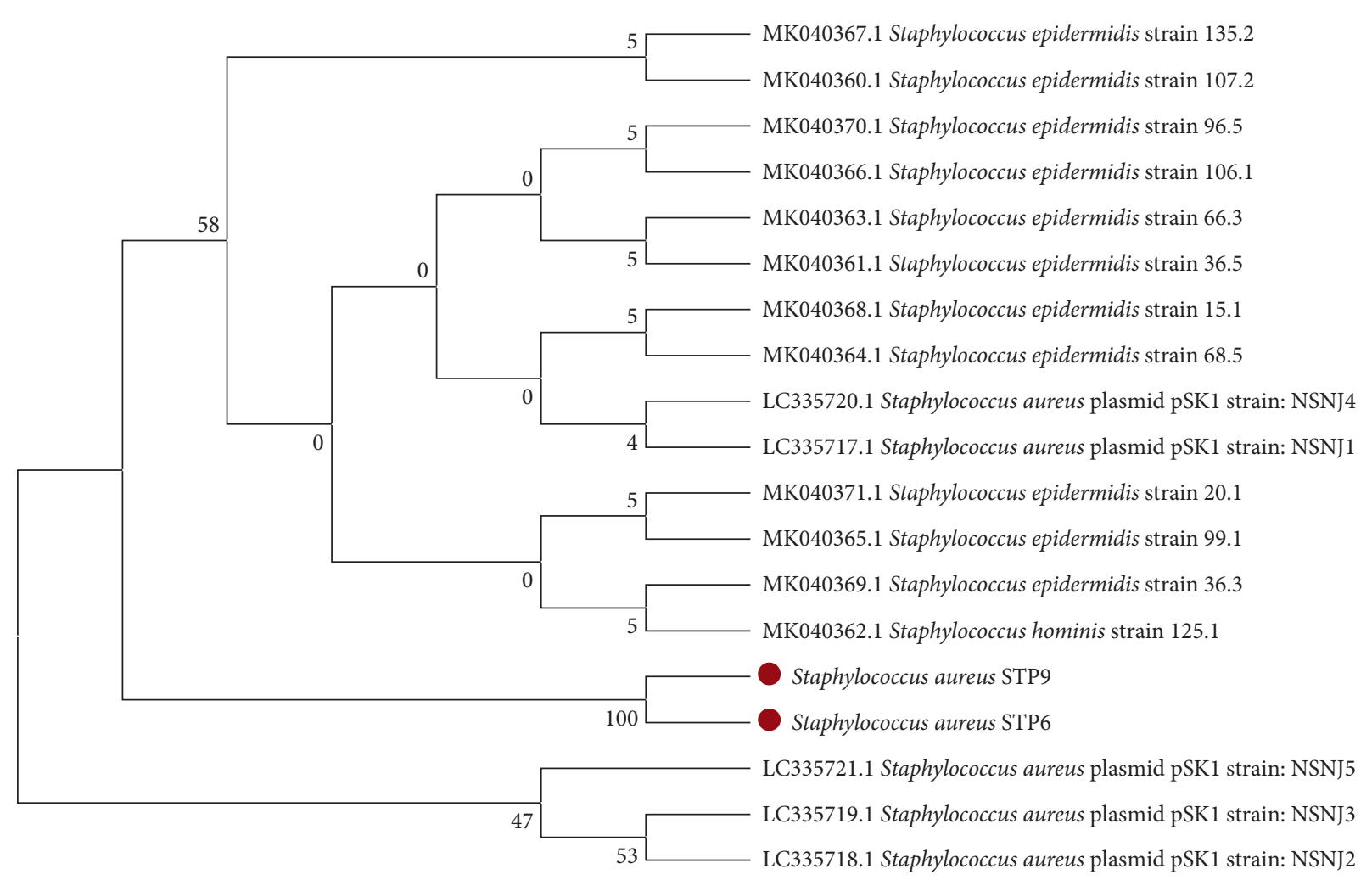

Figure 1: Phylogenetic tree constructed for 17 different qacA proteins extracted from GenBank, together with two S. aureus isolates (STP6 and STP9) that were qacA gene positive in this study. The tree was constructed using MEGA software (version 6) using maximum likelihood at 1000 replica.

Streptococcus, and Bacillus species, respectively, from barbing clippers in Benin City, Nigeria. This study finding was contrary to the findings of Stanley et al. [8], who reported a higher bacterial contamination of dryer although clippers were part of the study. Naz et al. [10] also reported $100 \%, 100 \%$, and $88 \%$ of $S$. aureus contamination in sponge, brush, and wax, respectively, from cosmetic tools used in beauty salons from different areas of Lahore, Pakistan. The higher bacterial contaminations observed from clipper in this study could be due to the improper sterilization or the ineffectiveness of the disinfectant used by these salon operators although the majority of studied salons operators 
claimed to sterilize or disinfect the tools after use on each client.

The higher bacteria resistance to sodium hypochlorite $1 \%$ was in line with findings of Al-Jubory et al. [42] who reported resistance of $P$. aeruginosa isolated in AL-Hilla Teaching Hospital Iraq to sodium hypochlorite 6\%. This was contrary to the findings of Awodele et al. [20], who also reported susceptibility of $P$. aeruginosa and $B$. subtilis isolated from Barbing salons Clipper in Benin City, Edo State, Nigeria, to sodium hypochlorite $100 \%$ concentration although the concentration was higher than that used in this study. The differences in resistance observed from these studies could be due to the difference in the concentration of sodium hypochlorite used or difference in nature of the bacterial isolates used.

The low resistance to methylated spirit was in line with findings of Awodele et al. [20] who reported susceptibility of $P$. aeruginosa and $B$. subtilis to methylated spirit with 20 and $22 \mathrm{~mm}$ zone of inhibition. The lower resistance of the isolated bacteria to the methylated spirit in this study could be linked to the knowledge of salon operators as in this study, and it showed that most salon operators are knowledgeable about guidelines designed by UNBS, which recommended the usage of methylated spirit at $70 \%$ as a disinfectant for basins and metal tools and as in the study by Awodele et al. [20]. Proper cleaning of salon equipment with right disinfectant concentration reduces the risk of bacteria developing resistant to disinfectants. This was demonstrated by a study by Awodele et al. [20] who reported $100 \%$ B. subtilis and P. aeruginosa resistance to methylated spirit at concentrations of $6.25 \%$, $12.5 \%$, and $50 \%$ although the disinfectant (methylated spirit) showed antibacterial activity at $100 \%$ concentration.

Presence of bacteria pathogens within the community is chained from animal and food industries to the community or hospitals to community [39]. These sectors use disinfectant in their day to day activities. In this study, detection of qac genes was limited to resistant $S$. aureus but not the other resistant strains due to lack of literature on the detection of qac genes in other species. The prevalence of qacA/ $\mathrm{B}$ and $q a c \mathrm{C}$ genes associated with disinfectant resistance reported in this study is lower than the prevalence reported by a study conducted within the community of Hong Kong, China, on an automated teller machine, in which $11 \%$ of the isolated S. aureus carried qacA/B and less than $2 \%$ had qacC/ smr, while qacC/smr was found in $14 \%$ and qacA/B in $26 \%$ of the coagulase-negative Staphylococci (CNS) isolates [43]. This was contrary to the findings of Wong et al. [44] who reported zero prevalence of qacC/smr and qacA/B genes associated with disinfectant genes in methicillin-resistant $S$. aureus isolated in porcine although another gene associated with disinfectant resistant such as qacG was detected. The genes qacA/B and qacC/smr have all been detected from $E$. coli resistant to beta-lactam antibiotics in bovine, caprine, and other food-related coagulase-negative Staphylococcus spp. such as S. epidermidis, S. saprophyticus, S. cohnii, and S. hominis $[39,45,46]$.

However, the presence of qac genes associated with disinfectant resistant was also reported in many studies involving a hospital or clinical sample [47-52]. Study on qac genes associated with disinfectant resistance in African countries seems to be scarce and was reported to be higher in Asia [39]. For example, Bjorland et al. [46] reported 7.5\% of qacA/B genes in clinical isolates of $32 \%$ MRSA in Japan. Similarly, in a study conducted by Conceição et al. [51], from three African countries (Angola, São Tomé and Príncipe, and Cape Verde) among 82 methicillin-resistant S. aureus (MRSA) and 219 methicillin-susceptible $S$. aureus (MSSA) isolated from previous nasal carriage showed $40.5 \%$ qacA/B genes.

The phylogenetic tree analysis constructed using maximum likelihood method at 1000 number of bootstrap replications showed that the two S. aureus isolates (STP9 and STP6) form a different clade from known Staphylococcus spp. that harboured antiseptic resistance protein (qacA) gene extracted from Gene bank (NCBI). All the isolates used for comparisons were mostly isolated from clinical samples as compared to ours which were isolated from environmental sources (salons). Secondly, most of the antiseptic resistance protein (qacA) gene sequences, Staphylococcus spp. extracted from Gene bank (NCBI) were whole-genome sequences, while our isolates were partial sequences, and this could explain the reason why the two $S$. aureus isolates (STP9 and STP6) form a new clade in the tree. The results of this finding were in line with the findings of Wassenaar et al. [39], who reported variations in the phylogenetic analysis of antiseptic resistance protein ( $q a c \mathrm{~A})$ gene sequences of different species of Staphylococci sequences extracted from Gene bank.

\section{Conclusion}

Our study has shown that bacteria contamination on salon equipment in Bushenyi district of Uganda is common, with S. epidermidis commonly isolated. Most disinfectant-resistant isolates were commonly reported against sodium hypochlorite $1 \%$. The disinfectant-resistant S. aureus isolated had either qacA or qacC genes. Furthermore, phylogenetic analysis of the two Staphylococci spp. sequences showed that they harboured qacA genes. Presence of disinfectant-resistant $S$. aureus harbouring qac genes from these studied salons showed the need for frequent proper sensitization of these salons' operators on the proper use of disinfectants by following the biosafety guideline of salon operation to cub development of disinfectant-resistant genes among the bacterial community of salons which can spread within the community. However, there is a need for further study on characterization and detection of the qac genes of other bacteria species isolated from salon tools from this studied area as this can help in proper diagnosis and treatments of diseases caused by these bacteria.

\section{Data Availability}

The data in tables and figures used to support the findings of this study are included in the article.

\section{Conflicts of Interest}

All authors declare that there are no conflicts of interest regarding the publication of this paper. 


\section{Acknowledgments}

The authors are thankful to the laboratory technologists of Microbiology and Immunology Laboratory of Kampala International University for their guidance and support that allowed this research work to be a success.

\section{References}

[1] WHO, The Global Epidemiology of Infectious Diseases, Goldman's Cecil Medicine, WHO, Geneva, Switzerland, 24th edition, 2011.

[2] UNAS, CDDEP, GARP-Uganda, Y. Mpairwe, and S. Wamala, Antibiotic Resistance in Uganda: Situation Analysis and Recommendations, Uganda National Academy of Sciences, Kampala, Uganda, 2015.

[3] K. U. Jansen, C. Knirsch, and A. S. Anderson, "The role of vaccines in preventing bacterial antimicrobial resistance," Nature Medicine, vol. 24, no. 1, pp. 10-19, 2018.

[4] F. S. Afsar, "Skin infections in developing countries," Current Opinion in Pediatrics, vol. 22, no. 4, pp. 459-466, 2010.

[5] M. S. Wazir, S. Mehmood, A. Ahmed, and H. R. Jadoon, "Awareness among barbers about health hazards associated with their profession," Journal of Ayub Medical College, Abbottabad: JAMC, vol. 20, no. 2, pp. 35-38, 2013.

[6] L. Mancini, M. Figliomeni, C. Puccinelli et al., "A descriptive survey on microbiological risk in beauty salons," Microchemical Journal, vol. 4, no. 2, pp. 2-27, 2017.

[7] P. Barn and T. Chen, "Infections associated with personal service establishments: piercing and tattooing," Journal of the Canadian Institute of Public Health Inspectors, 2012.

[8] M. i. C. Stanley, O. E. Ifeanyi, O. E. Ifeanyi, O. K. Chinedum, and I. S. Onyekachi, "Evaluation of microbial contamination of tools used in hair dressing salons in Michael Okpara University of Agriculture, Umudike, Abia State," IOSR Journal of Dental and Medical Sciences, vol. 13, no. 7, pp. 22-27, 2014.

[9] S. Enemuor, M. Ojih, S. Isah, and O. Oguntibeju, "Evaluation of bacterial and fungal contamination in hairdressing and beauty salons," African Journal of Microbiology Research, vol. 7, no. 14, pp. 1222-1225, 2013.

[10] S. Naz, M. Iqtedar, Q. U. Ain, and K. Aftab, "Incidence of human skin pathogens from cosmetic tools used in beauty saloons in different areas of Lahore," Pakistan Journal of Scientific Research, vol. 4, no. 2, pp. 2-6, 2012.

[11] S. A. Sekula, "Nail salons can be risky business," Archives of Dermatology, vol. 67, no. 6, pp. 2009-2011, 2002.

[12] K. L. Winthrop, K. Albridge, D. South et al., "The clinical management and outcome of nail salon-acquired Mycobacterium fortuitum skin infection," Clinical Infectious Diseases, vol. 38, no. 1, pp. 38-44, 2004

[13] S. A. Hedderwick, A. Shelly, M. J. McNeil, P. A. Lyons, and A. K. Carol, Pathogenic Organisms Associated with Artificial Fingernails Worn by Healthcare Workers, University of Chicago Press, Chicago, IL, USA, 2011.

[14] A. K. Gira, A. H. Reisenauer, L. Hammock et al., "Furunculosis due to Mycobacterium mageritense associated with footbaths at a nail salon," Journal of Clinical Microbiology, vol. 42, no. 4, pp. 1813-1817, 2004.

[15] K. P. Redbord, D. A. Shearer, H. Gloster et al., "Atypical Mycobacterium furunculosis occurring after pedicures," Journal of the American Academy of Dermatology, vol. 54, no. 3, pp. 520-524, 2006.
[16] J. E. Stout, L. B. Gadkowski, S. Rath, J. A. Alspaugh, M. B. Miller, and G. M. Cox, "Pedicure-associated rapidly growing mycobacterial infection: an endemic disease," Clinical Infectious Diseases, vol. 53, no. 8, pp. 787-792, 2011.

[17] D. L. David, A. Edward, M. Z. Zaruwa, and P. A. Addass, "Barbing saloon associated fungal disease infection in Mubi, Adamawa State-Nigeria," World Journal of Medical Sciences, vol. 5, no. 1, pp. 17-21, 2010.

[18] L. Jiang, M. Li, J. Tang et al., "Effect of different disinfectants on bacterial aerosol diversity in poultry houses," Frontiers in Microbiology, vol. 9, p. 2113, 2018.

[19] M. A. Guimarães, A. Tibana, M. P. Nunes, and K. R. N. D. Santos, "Disinfectant and antibiotic activities: a comparative analysis in Brazilian hospital bacterial isolates," Brazilian Journal of Microbiology, vol. 31, pp. 193-199, 2000.

[20] O. Awodele, P. M. Emeka, H. C. Agbamuche, and A. Akintonwa, "The antimicrobial activities of some commonly used disinfectants on Bacillus subtilis, Pseudomonas aeruginosa and Candida albicans," African Journal of Biotechnology, vol. 6, no. 8, pp. 987-990, 2007.

[21] M. I. Omoruyi and M. I. Idemudia, "Comparative analysis of the antiseptic properties of some disinfectants on bacteria and fungi of public health importance isolated from barbing clippers," Journal of Asian Scientific Research, vol. 1, no. 2, p. 65, 2011.

[22] O. Suzer, "Disinfectants and andantiseptics," Journal of Pharmaceutical Science and Technology, vol. 30, no. 6, p. 2108, 2008.

[23] UBOS, National Population and Housing Census, 2014-Area Specific Profile Series, UBOS, Kampala, Uganda, 2017.

[24] T. G. da Silva Paim, K. C. Reiter, and C. F. P. A. de Oliveira d'Azevedo, "MALDI-TOF MS performance to identify gram-positive cocci clinical isolates in Porto Alegre," Brazil Journal of Infection Control, vol. 2, pp. 112-116, 2013.

[25] M. Odoki, A. A. Aliero, J. Tibyangye et al., "Prevalence of bacterial urinary tract infections and associated factors among patients attending hospitals in Bushenyi district, Uganda," International Journal of Microbiology, vol. 2019, Article ID 4246780, 8 pages, 2019.

[26] F. Günther, M. Scherrer, S. J. Kaiser, A. DeRosa, and N. T. Mutters, "Comparative testing of disinfectant efficacy on planktonic bacteria and bacterial biofilms using a new assay based on kinetic analysis of metabolic activity," Journal of Applied Microbiology, vol. 122, no. 3, pp. 625633, 2017.

[27] N. Silivano, I. Ntulume, I. Ntulume et al., "In-vitro antibacterial activity of ethanolic and aqueous leaf crude extracts of Solanum nigrum (black night shade) of Bushenyi district-Uganda on selected enteric bacteria," International Journal of Innovative Approaches in Science Research, vol. 2, no. 4, pp. 112-125, 2018.

[28] Clinical and Laboratory Standards Institute (CLSI), Performance Standards for Antimicrobial Susceptibility Testing, Clinical and Laboratory Standards Institute, Wayne, PA, USA, 26th edition, 2016.

[29] L. Guo, M. Long, Y. Huang et al., "Antimicrobial and disinfectant resistance of Escherichia coli isolated from giant pandas," Journal of Applied Microbiology, vol. 119, no. 1, pp. 55-64, 2015.

[30] Z. Tarek, K. Bochra, M. Hanene, and B. Amina, "Detection of macrolide and disinfectant resistance genes in clinical Staphylococcus aureus and coagulase-negative staphylococci," BMC Research Notes, vol. 4, p. 453, 2011. 
[31] Y. W. Xiao, L. Tao, J. Bei, J. C. Li, Q. L. Xiao, and X. H. Wen, "Prevalence and molecular typing of the antiseptic resistance genes qacA/B among Staphylococcus aureus strains isolated in a teaching hospital," African Journal of Biotechnology, vol. 11, no. 47, pp. 10785-10791, 2102.

[32] N. Saber, N. J. Kandala, and H. A. Mohammed, "Detection a new antiseptic resistant variant of qac gene in some multi drug resistant Staphylococcus aureus isolated from different clinical sources," Baghdad Science Journal, vol. 16, no. 3, pp. 571-579, 2019.

[33] H. Nakaminami, N. Noguchi, and M. Sasatsu, "Fluoroquinolone efflux by the plasmid-mediated multidrug efflux pump qacB variant qacBIII in Staphylococcus aureus," Antimicrobial Agents and Chemotherapy, vol. 54, no. 10, pp. 4107-4111, 2010.

[34] S. Hassanzadeh, R. Mashhadi, M. Yousefi, E. Askari, M. Saniei, and M. R. Pourmand, "Frequency of efflux pump genes mediating ciprofloxacin and antiseptic resistance in methicillin-resistant Staphylococcus aureus isolates," Microbial Pathogenesis, vol. 111, pp. 71-74, 2017.

[35] Z. Zhou, M. Zhang, H. Li et al., "Prevalence and molecular characterization of Staphylococcus aureus isolated from goats in Chongqing, China," BMC Veterinary Research, vol. 13, no. 1, p. 352,2017

[36] A. Addetia, A. L. Greninger, A. Adler et al., "A novel, widespread qacA allele results in reduced chlorhexidine susceptibility in Staphylococcus epidermidis," Antimicrobial Agents and Chemotherapy, vol. 63, no. 6, Article ID e02607, 2019.

[37] M. Ruddy, M. Cummins, and Y. Drabu, "Hospital hairdresser as a potential source of cross-infection with MRSA," Journal of Hospital Infection, vol. 49, no. 3, pp. 225-227, 2001.

[38] B. Ataei, K. Shirani, S. M. Alavian, and M. Ataie, "Evaluation of knowledge and practice of hairdressers in women's beauty salons in isfahan about hepatitis B, hepatitis C, and AIDS in 2010 and 2011," Hepatitis Monthly, vol. 13, no. 3, 2013.

[39] T. Wassenaar, D. Ussery, L. Nielsen, and H. Ingmer, "Review and phylogenetic analysis of qac genes that reduce susceptibility to quaternary ammonium compounds in Staphylococcus species," European Journal of Microbiology and Immunology, vol. 5, no. 1, pp. 44-61, 2015.

[40] L. Dadashi and R. Dehghanzadeh, "Investigating incidence of bacterial and fungal contamination in shared cosmetic kits available in the women beauty salons," Health Promotion Perspectives, vol. 6, no. 3, pp. 159-163, 2016.

[41] K. Rideout, Comparison of Guidelines and Regulatory Frameworks for Personal Services Establishments, National Collaborating Centre for Environment Health, Vancouver, Canada, 2010.

[42] S. A. Al-Jubory, H. S. Naher, and R. H. Saleh, "A study of efficacy of disinfectants and bacterial contamination in AlHilla teaching hospital," Medical Journal of Babylon, vol. 9, no. 4, pp. 890-900, 2012.

[43] M. Zhang, M. O'dononghue, and M. V. Boost, "Characterization of staphylococci contaminating automated teller machines in Hong Kong," Epidemiology and Infection, vol. 140, no. 8, pp. 1366-1371, 2012.

[44] T. Z. Wong, M. Zhang, M. O’Donoghue, and M. Boost, "Presence of antiseptic resistance genes in porcine methicillin-resistant Staphylococcus aureus," Veterinary Microbiology, vol. 23, no. 2-4, pp. 977-979, 2013.

[45] M. S. Sidhu, E. Heir, H. Sørum, and A. Holck, "Genetic linkage between resistance to quaternary ammonium compounds and $\beta$-lactam antibiotics in food-related
Staphylococcus spp," Microbial Drug Resistance, vol. 7, no. 4, pp. 363-371, 2001.

[46] J. Bjorland, T. Steinum, B. Kvitle, S. Waage, M. Sunde, and E. Heir, "Widespread distribution of disinfectant resistance genes among Staphylococci of bovine and caprine origin in Norway," Journal of Clinical Microbiology, vol. 43, no. 9, pp. 4363-4368, 2005.

[47] M. M. Alam, N. Kobayashi, N. Uehara, and N. Watanabe, "Analysis on distribution and genomic diversity of high-level antiseptic resistance genes qacA and qacB in human clinical isolates of Staphylococcus aureus," Microbial Drug Resistance, vol. 9, no. 2, pp. 109-121, 2003.

[48] M. N. Shamsudin, M. A. Alreshidi, R. A. Hamat et al., "High prevalence of $\mathrm{qacA} / \mathrm{B}$ carriage among clinical isolates of meticillin-resistant Staphylococcus aureus in Malaysia," Journal of Hospital Infection, vol. 81, no. 3, pp. 206-208, 2012.

[49] J. Longtin, C. Seah, K. Siebert et al., "Distribution of antiseptic resistance genes qacA, qacB, andsmrin methicillin-resistant Staphylococcus aureus isolated in Toronto, Canada, from 2005 to 2009," Antimicrobial Agents and Chemotherapy, vol. 55, no. 6, pp. 2999-3001, 2011.

[50] J. S. McDanel, C. R. Murphy, D. J. Diekema et al., "Chlorhexidine and mupirocin susceptibilities of methicillin-resistant Staphylococcus aureus from colonized nursing home residents," Antimicrobial Agents and Chemotherapy, vol. 57, no. 1 , pp. $552-558,2013$.

[51] T. Conceição, C. Coelho, H. de Lencastre, and M. Aires-deSousa, "High prevalence of biocide resistance determinants in Staphylococcus aureus isolates from three African countries," Antimicrobial Agents and Chemotherapy, vol. 60, no. 1, 2016.

[52] T. Goolam Mahomed, M. M. Kock, R. Masekela, E. Hoosien, and M. M. Ehlers, "Genetic relatedness of Staphylococcus aureus isolates obtained from cystic fibrosis patients at a tertiary academic hospital in Pretoria," South Africa Scientific Reports, vol. 8, p. 12222, 2018. 